\title{
Konflikty českého trampingu
}

JAN POHUNEK*

\section{Conflicts of the Czech Tramping}

\begin{abstract}
This paper the summarizes history of Czech subcultural movement named "tramping", especially its conflicts with mainstream culture during $20^{\text {th }}$ century. Tramping, as an unorganized informal youth escapist movement that combines outdoor recreation with hiking, social activities and ostensive mimicking of idealised American Wild West, was often claimed to be undecent and disturbing by the 1918-1938's Czechoslovak republic authorities. Another reason for increasing tension between "tramps" and authorities was related to the fact that tramping was originally mostly a blue-collar movement and was influenced by political left. Attempts to control it were, however, mostly unsuccessful. This pressure has increased after 1948, as the communist regime perceived "tramps" as corrupted youth and used violence and other forms of persecution to break their gatherings. The movement, now mostly apolitical, has dwindled in numbers in 1950s, but was again massively revived in 1960's, while keeping its role of an accessible, non-radical but slightly alternative free time activity. The years of "normalization" between 1968 and 1989 were marked by an increase in persecution, but the regime also attempted to manage the movement using various state-organized cultural events and press. Numbers of tramps have decreased after 1989, most of today's conlifcts are related to interference between specific way of hiking popular among "tramps" and interests of state organizations in the field of nature protection.
\end{abstract}

Keywords: Czech tramping, $20^{\text {th }}$ century, youth movement, subculture, mainstream culture, generational conflict

\section{Úvod}

Český tramping je svébytným, spontánně vzniklým hnutím mládeže, které během téměř sta let své existence prošlo řadou dílčích proměn a v současnosti jej lze považovat za svébytnou subkulturu, v níž jsou zastoupeny všechny věkové kategorie české a slovenské populace. Trampové jsou nicméně zároveň sociální skupinou, kterou nelze přesně vymezit - jednak proto, že hnutí má, narozdíl např. od skautingu, méně oficiální a dosti neorganizovaný charakter, především ale proto, že jeho podstata je dvojí - jde jak o formu sdružování, tak i o zpơsob trávení volného času. Jedním ze zvláštních rysů trampingu je skutečnost, že navzdory své dlouhé tradici a masové povaze (přítomné alespoň v některých obdobích) vždy byl a dosud je některými svými projevy na hranici legality či těsně za ní [Altman 2003: 259-260] a byl často způsobem, jak se vymezit vůči většinové společnosti. Povaha tohoto vymezování však v průběhu 20. století nabírala různou podobu.

Cílem tohoto příspěvku je poskytnout nástin vývoje komplikovaného vztahu trampů a „pađ’ourů“, jak bývají trampy jejich pasivní i aktivní antagonisté z řad většinové společnosti nazýváni [ $k$ etymologii slova „pad’our“ viz Pergelová 2004: 28]. Je ovšem

\footnotetext{
* Jan Pohunek, Ústav etnologie, Filozofická fakulta - Univerzita Karlova, nám. Jana Palacha 2, 11000 Praha 1. E-mail: prebral@seznam.cz; pohunek@muzeumjilove.cz
} 
nutné podotknout, že český tramping je fenoménem, který dosud není komplexně zhodnocen, $\mathrm{v}$ literatuře věnované tomuto tématu převažují práce orientované na období 1. republiky [Waic - Kössl 1992; Hurikán 1990] nebo regionálně zaměřené [Vinklát 2004]. Existující všeobecné práce navíc často jen opakují známá fakta z publikací předchozích, a jak správně upozorňuje ve své monografii o historii meziválečného trampingu na Rakovnicku Jan Krško, potenciál tématu dnes zřejmě spočívá především v pečlivém zhodnocení archivních pramenů a výpovědí pamětníků z jednotlivých regionů, pomocí kterého bude teprve možné vypracovat i moderní celkovou interpretaci trampingu s celostátní platností [Krško 2008: 20-32, 265-266]. Závěry, jež by mohly aspirovat na pozici definitivních vysvětlení jednotlivých aspektů fenoménu, tedy zatím asi dělat nelze, domnívám se ale, že některé projevy a charakteristiky trampingu, mezi něž patř́ i jeho pololegální postavení, si pro svou zajímavost z hlediska historické sociologie a sociologie mládeže přinejmenším zaslouží aktuální zmínku, která může sloužit i jako úvod do celé problematiky.

Počátky trampingu je možné přibližně datovat do doby krátce před 1. světovou válkou a souvisejí s vývojem skautského hnutí, do Čech zavedeného v roce 1912 [Břečka 1999: 23-30]. Kromě organizovaných skautů, woodcrafterů i členů dalších mládežnických a tělovýchovných organizací již tenkrát v Praze existovaly malé skupiny mladých lidí jezdících do přírody „na divoko“, v některých případech šlo o odrostlé skauty či osoby s jinými vazbami na hnutí podobná skautingu [Hurikán 1990: 14-15; Moidl - Moidlová 2010: 10]. Po 1. světové válce jejich počet výrazně vzrostl, mimo jiné i proto, že skautské hnutí nemělo dosud vypracovanou metodiku pro práci s mládeží nad 15 let, takže nedokázalo odrostlé členy svých oddílů úspěšně zaujmout, přestože měli o společný pobyt v prŕrodě zájem. „Divocí skauti“, jak byli první trampové tehdy označováni, si v té době začali budovat trvalejší tábořiště nazývaná „osady“, přičemž označení osada se částečně přeneslo i na jednotlivé kolektivy. Významný vliv na formování vnější podoby trampingu měly v této době zejména americké filmové westerny, jež byly nově promítány v československých kinech, spolu s dobrodružnou literaturou a cestopisy. „Divocí skauti“ začali rychle přebírat jednotlivé romantizované westernové prvky do svého slangu, tábornického vybavení, oblečení i chování. Ve 20. letech se pro vznikající hnutí postupně ujal i samotný dodnes používaný termín „tramping“, který byl zřejmě přejat z knih Jacka Londona o amerických tulácích - trampech. V závěru 20. let byl tramping již masovým hnutím a plně rozvinutou subkulturou, jejímž typickým představitelem byl mladý dělník, učeň či student, který na neděli odjížděl do romantické krajiny jižně od Prahy a tam se věnoval aktivnímu odpočinku v podobě ostenzivní hry napodobující reálie Divokého západu a současně neformálním společenským aktivitám, turistice, sportu a případně i amatérskému umění (hudba, literární a výtvarná tvorba). Základním typem trampských kolektivů byly jednotlivé osady, kromě nich ale existovali i trampové - samotáři [Hurikán 1990: 16-22; Waic - Kössl 1992: 11-18].

Hnutí mělo zpočátku především rekreační až únikový charakter. Pro trávení volného času formou trampingu byl ale příznačný i důraz na osobní volnost a neformální chování, který stavěl trampy do opozice vůči autoritám a úředním nařízením. Kořeny tohoto aspektu trampingu byly zřejmě převážně spjaté s běžnými psychologickými projevy dospívání, jako je hledání vlastní cesty, nezávislosti a uznání v kolektivu vrstevníků. Tramping byl také do jisté míry víkendovou hrou na vystoupení z většinové všední 
společnosti do idealizovaného světa, vytvářel si vlastní vnitřní pravidla a nemohl v plné míře respektovat pravidla vnější, nebot každý takový ústupek znamenal narušení soudržnosti vnitřního světa hry. V neposlední řadě je při úvahách nad svobodomyslným charakterem trampingu třeba zmínit i některé sociální a politické faktory, jako je traumatizující zkušenost první světové války nebo částečná příchylnost sociálních skupin, z nichž se rekrutovali první trampové, k politické levici, která se výrazněji projevila zejména během velké hospodářské krize.

Podíváme-li se na př́činy konkrétních konfliktů mezi trampy 20. let 20. století a většinovou společností, nalezneme několik opakujících se jevů. Prvním z nich je skutečnost, že řada prvorepublikových trampských osad byla chatová (další alternativou, zejména v počátcích trampingu, bylo ježdění pod stany), ale stavba chaty v lese, byt̉ na soukromém pozemku, podléhala celé řadě úředních regulací, takže mnohé $z$ nich vznikaly načerno [Waic - Kössl 1992: 24-30; Krško 2008: 80-86]. Venkovská společnost ale i přes občasné rušení klidu přijala trampy poměrně dobře, a to proto, že s sebou jako specifický druh rekreantů přinášeli možnost přivýdělku. Kritika trampingu zaznívala spíše z pozic úřadů, výletníků z měst a některých pedagogicky působících organizací. První výraznější vystoupení proti trampingu pocházelo od A. B. Svojsíka, zakladatele českého skautingu, který v článku nazvaném Bílá otrokyně v centru Evropy vykreslil na základě recesisticky pojatého „zákoníku“ jedné trampské osady a vlastních zkušeností trampy jako mládež, která popíjí alkohol, zneužívá dívky a provozuje v hojné míře vandalismus. Článek vyvolal jistou pozornost úřadů a četnictva, realističtější zprávy četníků působících v terénu ale ukazují, že výtržnosti tohoto typu nepřekračovaly běžnou míru a nebyly spojovány jen s trampy, ale i s jinými skupinami výletníků [Waic - Kössl 1992: 37-41; Krško 2008: 71-79]. Ve druhé polovině 20. let však konfliktů přibývalo, tramping byl kritizován zejména $\mathrm{z}$ hlediska mravnostního kvůli společnému táboření mladých párů a kvůli páchání různých drobných výtržností trampy [Waic - Kössl 1992: 44-45]. Za vyvrcholení snah o regulaci trampingu je možné považovat tzv. Kubátův zákon, vyhlášku zemského presidenta Hugo Kubáta platnou od roku 1931, která postihovala zejména společné táboření nesezdaných párů, pobíhání v nedostatečném úboru, zpívání nemravných popěvků, nošení zbraní a koupání na zakázaných místech. Vyhláška byla doprovázena oběžníkem, který upřesňoval, že policejní kontroly se mají selektivně zaměřit především na osoby, proti nimž je nutno zakročit, nikoli na členy „spořádaných“ organizací. Její vynucování, zpočátku zahájené řadou tvrdě vedených štár v trampských osadách [viz např. Tramp 1931/20: 4-5; Tramp 1931/21: 3], se ovšem postupně stávalo sporadickým a v roce 1935 byla $\mathrm{v}$ důsledku soudního sporu vedeného jedním z pokutovaných trampů zrušena Nejvyšším správním soudem [Waic - Kössl 1992: 51-56; Krško 2008: 100-101].

Snahy o regulaci trampingu, jakkoli fakticky nepř́liš účinné, nicméně vyvolávaly výraznou reakci mezi trampy, a to jak formou nedodržování „Kubátova zákona“ a kritiky chování úřadů v tisku, tak i prostřednictvím demonstrativních setkání trampů. Hnutí jako celek se stavělo ke snahám o vytvoření nějaké zastřešující organizace, která by jej zastupovala a sjednotila, spíše negativně. Takové pokusy nicméně existovaly, zmínit lze například Svaz trampů založený v roce 1928, Trampské obranné výbory z roku 1931 nebo Unii trampských osad. Žádný z těchto spolků, které byly obvykle spojeny s některým politickým křídlem v rámci hnutí, se ale nestal většinovým a obvykle zase rychle zanikl [Waic-Kössl 1992: 34-35; Krško 2008: 90-101]. Nejaktivnější byli v tomto ohledu levicoví 
až prosovětští trampové, kteří se také často dostávali do sporů s trampy umírněnými a apolitickými a jejichž sdružování a tiskové aktivity znepokojovaly prvorepublikové úřady [Waic - Kössl 1992: 57-59; Krško 2008: 90-92].

Jako sonda do toho, jak vnímala celou problematiku tato levicová část hnutí a jak se měnil její postoj k otázce míry politiky v trampingu, může být použit zejména satirický a informační týdeník Tramp vydávaný v letech 1929-1931 skupinou trampů kolem Gézy Včeličky a Karla Melíška (Melich). Významná část redaktorů a přispěvatelů Trampa patřila mezi členy komunistické strany a psala i pro Rudé právo, v jehož Večerníku rovněž existovala trampská rubrika [Melíšek 1929a: 10]. První a část druhého ročníku Trampa je možné považovat za kriticky orientované, ale ještě poměrně umírněné. Konfliktně jsou zde laděny především ironické polemiky s většinovým tiskem (např. Večer nebo Národní listy), který přinášel zprávy o morálně pohoršujících a rušivých výstřelcích trampů na hraně „morální paniky“ [k termínu viz např. Heřmanský - Novotná 2011: 100-102]. Zvláště výrazně byly kritizovány tiskoviny vydávané národně-socialisticky orientovaným politikem a novinářem Jiřím Stř́brným, a to především ve chvíli, kdy se pokusil uvést v Nedělním listě vlastní trampskou rubriku [viz např. Melíšek 1929b; anonym 1929a; anonym 1930b]. Část těchto textů byla zachycena prvorepublikovou cenzurou, zřejmě především kvůli jejich „urážlivému“ obsahu [anonym 1930a]. Jistý přelom znamenala trampská slezina na Jarovské pláni 8. června 1930, která se (zřejmě spíše náhodou) kryla s termínem tzv. Rudých letnic organizovaných komunisty a která byla pro obavy z radikálních vystoupení rozpuštěna četnictvem. Reakce na celou událost v Trampu byla rozhořčená, autoři textů ale stále považovali za nutné zmínit, že jsou sice přispěvateli Večerníku Rudého práva, své povinnosti ke komunistické straně ale plní nezávisle na práci v Trampu, který je nepolitický [Melíšek 1930; anonym 1930c]; na stránkách časopisu [např. čísla 24 a 26/1930] byly následně tištěny i polemické dopisy podporující nepolitický rozměr hnutí, samotná jejich existence ale svědčí o tom, že otázka již byla otevřena a byla považována za důležitou.

Ročník 1931 byl již podstatně radikálnější, včetně posílení rétoriky „boje proti pađourství“ [srov. např. Melišek 1931a]. Už od začátku roku na tom zřejmě měly podíl prosakující zprávy o přípravě „Kubátova zákona“. Tramp doporučoval pořádat protestní schůze a zakládat trampské obranné výbory [Melíšek 1931b], sám se na trampských aktivistických vystoupeních i výrazně podílel a hojně otiskoval rezoluce a podpůrné dopisy od řady trampských osad [anonym 1931a]. „Kubátův zákon“ byl považován za součást širšího plánu, jak odvést mládež od svobodného trampingu, a podpořit tak plán organizované povinné předvojenské výchovy. Změnil se i názor časopisu na otázku nepolitičnosti trampingu - ta začala být označována za neobhajitelnou a nepoliticky profilované trampské spolky (Unie trampských osad, časopis Naše osady) byly označovány za skupiny trampů, kteří ještě neprohlédli, nebo jsou přímo spojeni s nepřítelem [viz např. Tramp 14/1931; Tramp 15/1931, Tramp 24/1931; vše průběžně]. Zásadní rozkol mezi „nepolitickými“ a „politickými“ trampy znamenal protestní tábor v Pivovarské zahradě v Praze 19. května 1931, který se z větší části nesl v režii prokomunistických trampů (zástupce Našich osad hasící bojovnou náladu byl vypískán) a byl rozehnán policií [Tramp 21/1931: 3]. K usmíření obou stran, při kterém se dokonce redakce Trampa omluvila za některé př́liš osobní výpady i události z Pivovarské zahrady, došlo ale ještě téhož roku před celostátní trampskou slezinou 21.-22. listopadu 1931 [Tramp 39/1931: 3a 16]. 
Deklarované prokomunistické zařazení už si ovšem Tramp udržel, zvláštní dobový dokument v tomto ohledu představuje např́klad seriál popisující cestu skupiny několika představitelů levicových trampů do SSSR, který vycházel v číslech 28/1931 až 32/1931 a který sovětskou realitu značně idealizuje. V polovině 30 . let se situace postupně uklidnila, tramping byl do jisté míry přijat do většinové kultury, přičemž značnou roli zde hrála mimo jiné popularita trampské písně i skutečnost, že se hnutí stávalo módním a už od poloviny 20. let čím dál tím populárnějším např́ič sociálními vrstvami. Masovost trampingu dokonce už od přelomu 20. a 30. let vyvolávala obavy některých původních trampů, že hnutí mírí ke „spadouření“ [Waic - Kössl 1992: 31-33], kritizovány byly např́klad př́liš úhledné trampské osady [anonym 1929b] a obecně to, že „tramping je dnes móda, jezdí ovce“ [Dědek 1930]. Nepříznivého přijetí se dočkaly rovněž některé pokusy využít trampské motivy ve filmech určených pro širší veřejnost, zvláště špatně byl trampy přijat např́iklad film Osada mladých snů, který byl při svém uvedení do kin doslova vypískán [anonym 1931b]. V podstatě tedy docházelo k obvyklému jevu, kdy je nová subkultura potenciálně vykazující protestní rysy postupně popularizována, asimilována, zevšedněna a začleněna do obecných společenských a kulturních struktur. Oproti „radikálnímu“ Trampu je za trampský tisk příznačný pro toto období možné považovat časopis Ahoj na neděli, který vycházel v letech 1933-1943. V trampských rubrikách se věnoval především romantické stránce trampingu a politický rozměr v něm měly $\mathrm{v}$ podstatě jen některé karikatury F. Bidla či A. Pelce [např. čísla 1933/1 a 1934/11].

Tento vývoj byl však kolem poloviny 20. století narušen historickými událostmi, které zasáhly celou českou společnost. Druhá světová válka ještě pro tramping nepředstavovala zásadní krizi, i když jej poněkud utlumila. Omezení, která trampy v této době ovlivňovala a znesnadňovala jim jejich činnost, nebyla zaměřena přímo proti hnutí jako takovému jako např́iklad u skautingu, ale byla součástí obecných projevů nacistického totalitního režimu a válečné situace. Nejvýraznějším specifickým omezením trampingu bylo patrně zabírání trampských chat, např́klad při vyhlášení vojenského cvičiště na Neveklovsku nebo stavbě podzemních továren v tunelech Posázavského Pacifiku, a případně i jejich likvidace jako potenciálních partyzánských úkrytů. Za zmínku však rozhodně stojí působení některých trampů nebo celých osad v domácím odboji i zahraničních spojeneckých armádách - a dříve i účast v interbrigádách ve španělské občanské válce [Berka 1991; 49-51; Waic - Kössl 1992: 91-98; Vinklát 2004: 38-39]

Výraznou změnu představovalo až období po komunistickém převratu v roce 1948. Nová diktatura usilovala podle sovětského vzoru o sjednocení všech spolků pracujících s mládeží do jednoho ideologizovaného celku reprezentovaného Svazem československé mládeže. Ostatní organizace jako například Sokol nebo Junák byly komunisty infiltrovány a postupně rušeny. Přednostní byla zejména likvidace skautingu a tvrdá perzekuce těch jeho činitelů, kteří se nestáhli nebo nezačali přímo kolaborovat [podrobně Břečka 1999: 201 a dále]. V případě trampingu, na který se pozornost státních orgánů zaměřila ve větší míře až po rozbití skautského hnutí, nebylo možné tento odzkoušený přístup uplatnit - neexistovala žádná jednotná organizace, kterou by bylo možné napadnout, pouze jednotlivé trampské spolky a osady, často navíc bez formální registrace. Tramping, mimo jiné i pro své spojení s Amerikou, byl ale z ideologického hlediska jednoznačně nepřijatelný a na jeho levicový aspekt nebyl brán zřetel [Kučerová 1997: 13-14]. Konkrétní útoky režimu na trampy probíhaly zejména formou šikany trampů při policejních 
kontrolách na nádražích, které byly často spojené se zabavováním osobních věcí, nebo prostřednictvím brutálních přepadů trampských potlachů. Podobně jako další potenciálně problémové aktivity patřil samozřejmě i tramping mezi oblasti lidské činnosti pokryté dohledem bezpečnostních složek. Některé z tradičních trampských prvorepublikových chatových osad přežívaly nadále, nacházely se ale v útlumu a mladých trampů bylo až do konce 50. let poměrně málo. Našli mezi nimi ale místo i někteří bývalí skauti, kteří přitom neopouštěli ideu skautingu do té míry, jako tomu bylo u divokých skautů 20. let, a trampské hnutí se obecně se skautingem sbližovalo, což vedlo i k přejímání skautské symboliky trampy [Vinklát 2004: 52, 55, 59; Kučerová 1997: 13-15; Krško 2008: 69]. Dalším jevem, který s sebou 50. léta přinesla, bylo posílení koncepce aspektu trampské osady jako skupiny osob, nikoli nutně osady chatové - mezi trampy mladší generace bylo více skupin, jež (narozdíl od prvorepublikových trampských osad) neměly (a často ani nemohly mít) vlastní trvalé tábořiště [Kučerová 1997: 15].

$\mathrm{K}$ renesanci trampingu došlo postupně v 60 . letech 20 . století a souvisela zřejmě nejen s pomalým uvolňováním komunistického režimu, ale nepřímo též s novými neformálními hnutími mládeže v USA, jako byly beat generation nebo hippies. Tramping byl v tomto kontextu opět pasivně protestní, umírněnou a únikovou alternativou, čímž v podstatě navazoval na svoje prvorepublikové pojetí. Jeho forma byla ale již poněkud odlišná. Oproti masovému chatovému osadničení, spojenému často se sportem, dávali mladí trampové větší přednost toulání se v menších skupinách a ježdění na skromnější lesní campy. Výraznou změnu prodělal i trampský hudební projev - moderní trampská hudba, z pozic tradiční trampské hudby někdy i kritizovaná, se výrazně inspirovala moderní country a folkem a kromě nevážných a sentimentálních motivů typických pro tradiční trampskou píseň se začala soustředit i na aktuální současný život trampů. Dá se říci, že tato generace představovala novou vlnu českého trampingu a byla sociálně i regionálně diferencovanější a více individualistická [Vinklát 2004: 71; Kučerová 1997: 19-20]. Počátky této změny je možné datovat přibližně do let 1961-64, kdy sice ještě probíhaly brutální protitrampské policejní zásahy, ale již se poprvé v tisku začaly objevovat články stavící se k fenoménu trampingu pozitivně. Obhajoba trampingu na stránkách oficiálních tiskovin byla zpočátku stavěna především na snaze rozlišovat slušné trampy a chuligánské „kovbojíčky“, obracela se tedy zejména proti zažitému obrazu trampa jako hejska a potenciálně kriminálního výtržníka [např. Smoljak 1961]. Tramping byl také v rámci mírné připuštěné kritiky činnosti ČSM používán jako důkaz toho, že mládež má zájem o aktivity v př́rodě a je jen třeba ji lépe zaujmout, aby opustila neorganizovanou činnost a zapojila se do organizovaných aktivit [anonym - Valigurová 1963]. Svaz československé mládeže se $\mathrm{v}$ návaznosti na to ve 2 . polovině 60 . let pokoušel dostat hnutí pod kontrolu pořádáním trampských a tábornických akcí pod svými křídly, v roce 1968 pak organizační vývoj vyvrcholil založením nezávislé a nepolitické České tábornické unie, ve které byly zapojeny i některé trampské osady [Kučerová 1997: 17-18]. Ani $\mathrm{v}$ tomto případě ale nelze říci, že by nově vzniklé organizace byly jednoznačnou reprezentací převážné části trampského hnutí, které už navíc $\mathrm{v}$ tomto roce bylo obecně akceptováno. Během vyvrcholení tzv. Pražského jara také už bylo díky uvolnění cenzury možné namísto pouhého zdůrazňování kladů trampingu možné i přímo kritizovat jeho potlačování v letech dřivějších [srov. např. Tunkl - Weigel 1968], existovaly samostatné trampské časopisy, nezávislé na prostoru poskytnutém např. v tiskovinách ČSM. Zmínit 
lze v tomto ohledu například „ostravský“ Tramp. O roli České tábornické unie a jejím vztahu k trampingu byla mezi trampy a činovníky ČTU vedena nejen v tomto časopise poměrně intenzivní veřejná diskuze, ve které se trampové ohrazovali proti tomu, aby Unie hovořila „jejich jménem“ [viz např. Tramp 2/1969: 10-11 a 4/1969: 10-11].

Toto období skončilo s nástupem normalizace, která s sebou, podobně jako v jiných oblastech lidské činnosti, opět přinesla větší míru ideově podmíněné regulace, a to ve dvou vlnách - nejprve v návaznosti na potlačení Pražského jara a podruhé po vydání nového Lesního zákona v roce 1976 [Petrová 2009: 62-63]. Obnovení cenzury znamenalo zákazy trampských časopisů, navrátila se policejní šikana na nádražích i na trampských setkáních, došlo také k likvidaci celé řady trampských tábořišt a zabírání chat např. pro lesnické potřeby nebo z důvodu vyhlašování chráněných území [Vinklát 2004: 156-157; Kučerová 1997: 23]. Jako přehled právních problémů, s nimiž se trampové museli potýkat, může posloužit např́klad samizdatově vydávaná trampská právní poradna Jarmily Doležalové-Wickie [Doležalová 1979a a Doležalová 1979b] - šlo především o střety spojené s pořádáním potlachů, kontrolami totožnosti, osobními prohlídkami a tiskovým a autorským zákonem.

Perzekuce nicméně v 70. a 80. letech nebyla tak tvrdá ani tak častá jako v letech padesátých, ostatně i počet trampů byl po oživení celého hnutí v předchozí dekádě výrazně vyšší. Režim se kromě represe také snažil udržet si kontrolu nad trampingem i měkčími prostředky, včetně jeho omezeného akceptování, které se projevovalo např́iklad využitím festivalu Porta nebo pokrytím trampské tematiky časopisem Mladý svět, kde vycházela rubrika Táborový oheň. Ta byla poprvé zveřejněna v čísle 11/1964 a po přestávce na začátku 70. let byla vydávána i za normalizace. Její podoba z 80 . let bývala kritizována za to, že se snaží převychovat trampy v ochránce přírody nebo konzumní návštěvníky festivalů [Petrová 2009: 64]. Oba tyto komunikační prostředky měly v podstatě monopol na výklad problémů trampského hnutí, neznamená to ale, že by zastávaly okatě prorežimní stanovisko nebo že všichni, kdo se na jejich činnosti podíleli, by byli přesvědčenými zastánci státní ideologie - v podstatě zde byla nabízena možnost seberealizace za cenu úředního dohledu, který částečně toleroval kulturní projevy trampingu, ale nepřipouštěl kritickou diskuzi. Mimo oficiální struktury nicméně existovala poměrně bohatá trampská samizdatová scéna, proti níž StB zasahovala i navzdory tomu, že většina trampských samizdatů vůbec neměla politický rozměr a věnovala se spíše trampskému životu a literární a umělecké tvorbě trampů [Kučerová 1997: 22-23; Petrová 2009: 61-75; Vinklát 2004: 182-183].

Po roce 1989 počet trampů výrazně poklesl. Tento jev není dosud dostatečně zmapován, jako hlavní příčina bývá ale uváděn zánik potřeby „vnitřního exilu“, která se přirozeně spojovala s únikovým aspektem trampingu, dále pak také nárůst možností seberealizace, které trampingu konkurují, a obecně proměna zájmů mladé generace. Tramping nicméně existuje nadále a jeho základ patrně tvoří tvrdé jádro hnutí představované trampy, kteří jej považují za svůj životní styl či hlavní rekreační aktivitu. Jako celek není nijak úředně postihován, existují nicméně lokální konflikty, a to zejména se zájmy ochrany přírody. Ty se $\mathrm{v}$ průběhu 2. poloviny 90 . let a začátku 21. století projevovaly především v trampy oblíbených oblastech, v nichž byl zpřísněn režim ochrany přírody (například v NP Českosaské Švýcarsko nebo na širším Českolipsku a v Českém ráji) a kde se rozeběhla rozsáhlá likvidace trampských campů. Tento problém je stále předmětem diskuze, 
jež probíhá částečně i na oficiální a odborné rovině [srov. např. Jenč - Peša 2006; různé diskuze na www.ontheroads.net; www.roverky.cz].

Z výše uvedeného přehledu vývoje českého trampingu se zdá být patrné, že trampské hnutí, jakkoli je možné jej považovat za subkulturu vymezující se vůči kultuře většinové, nikdy nebylo subkulturou vysloveně protestní. Od počátku mělo únikový charakter, vytvářelo si vlastní svět, který ale obsahoval výrazný rozměr hry a neprojevoval se formováním plnohodnotných programově alternativních komunit jako například v případě hippies nebo squattingu. Trampské chatové osady, i když v nich někteří trampové mohli pobývat delší dobu, byly spíše místem setkávání a společenského života. Aktivní vymezování se vůči většinové kultuře nebylo vlastní celému hnutí, za první republiky se vázalo především na jeho levicový proud, jinak ale bylo spíše obrannou reakcí, která zesilovala v dobách, kdy byl tramping celkově potlačován nebo v př́ípadě různých lokálních konfliktů. Odpor vůči některým aktivitám reprezentantů většinové kultury - at̉ už šlo o četnictvo, komunistickou policii nebo jenom bezohledné „mastňáky“ na výletě - probíhal především ve verbální rovině a prostřednictvím trampského tisku a literární tvorby [srov. např. Waic - Kössl 1992: 37, 49], méně pak např́íklad formou drobných, spíše spontánních protiakcí, které měly podobu recese nebo drobného vandalismu (poškozování turistických značek, prvomájové výzdoby, vypouštění pneumatik automobilů...) [osobní sdělení M. Korba; dále srov. např. Trempoviny 3/1993]. Největšími veřejnými vystoupeními trampů byly prvorepublikové protesty proti „Kubátovu zákonu“. V době komunistické totality byl odpor vůči režimu převážně pasivní, bez vyhledávání přímé konfrontace, a byl vyjadřován únikem do vlastního světa s odlišnými pravidly, jisté formy vnitřního exilu. Dá se říci, že aktivní roli při vytváření konfrontačních situací naopak hrál samotný komunistický režim, který kvůli své potřebě kontroly všech složek společnosti postihoval i takové nezávislé aktivity, které nebyly namířeny přímo proti němu.

Podíváme-li se na samotné příčiny jednotlivých střetů trampů s většinovou společností, objevuje se pravidelně typický rys generačního konfliktu reprezentovaný snahou starších generací regulovat „nepřístojné“, rušivé a z hlediska zažité morálky obecně pochybné chování mládeže. Tento rozměr je patrný jak v době před druhou světovou válkou, tak i za komunistického režimu, kdy trampové v podstatě neměli povahu organizovaných „ideových protivníků“ jako tomu bylo u skautingu, ale bylo na ně spíše nahlíženo svrchu jako na závadovou a pomýlenou mládež, výtržníky a kriminálníky [srov. Kučerová 17]. Druhá příčina konfliktů leží v jednotlivých střetech zájmů, které se týkají především zpơsobu, jakým trampové využívají krajinu - tramping akcentuje volné toulání včetně táboření na libovolném vybraném místě, což jej opakovaně dostává do střetů s majiteli pozemků, lesníky, orgány státní ochrany př́rody apod. Za zvláště problémové je možné označit ty oblasti, kde má tramping dlouholetou intenzivní tradici a kde se náhle změní režim využívání daného území - například zřízením přírodní rezervace či národního parku, zpřísněním dosud jen volně vynucovaných pravidel chování nebo i zintenzivněním masové turistiky. Vzniklé konflikty navíc komplikuje otevřenost a neorganizovanost trampingu, ke kterému se mohou hlásit různé osoby a skupiny osob, které mají různou povahu a spolu se znají jen volně, což neposkytuje např́iklad ochraně přírody jistotu, že se všichni návštěvníci lokality budou chovat podle pravidel dohodnutých s jednou skupinou trampů, a mezi trampy samotnými zase přispívá k šíření poplašných fám, třebas o možné likvidaci oblíbených tábořište 
Trampové mají také omezenou možnost, jak komunikovat se státními organizacemi - zatímco s majitelem pozemku nebo lesníkem se lze dohodnout na osobní bázi a neformálně, komunikace s úřady předpokládá přijetí formalizovaných způsobů komunikace, které jsou vlastní byrokracii, avšak zcela cizí „duchu“ trampingu. Jako př́klad je možné uvést např́íklad situaci, ke které došlo v souvislosti s již zmíněnou likvidací trampských campů na širším Českolipsku na počátku 21. století - skupina trampů, která se pokusila bránit svoje pozice a názor na problematiku i prostřednictvím oficiální komunikace s orgány ochrany přírody a založením občanské iniciativy „Roverští patrioti“, byla okamžitě některými jinými trampy kritizována, že se snaží vystupovat jako jediný zástupce trampského hnutí, „privatizuje si“ oblast, o kterou byl veden spor, stanovuje vlastní pravidla chování v přírodě a institucionalizuje tramping, čímž se postupně dostává na stranu „nepř́tele“ [různé diskuze na www.ontheroads.net; www.roverky.cz]. Svým způsobem zde na základní úrovni jde o obdobu rozporu, který mohli pocitovat například lidé účastnící se oficiálně povolených trampských aktivit za normalizace nebo organizátoři trampských demonstrací za první republiky. Ve všech př́padech byla formální organizovanost a komunikace s úřady považována částí hnutí za něco nepatřičného a za potenciální ohrožení trampingu jako celku, a to i proto, že šlo o narušování hranic sociálních kontextů (tramp jako člověk na oficiálních strukturách nezávislý versus občan, který na nich politicky participuje). Neznamená to, že by tramp nemohl být politicky činným občanem, ale po apolitizujícím vývoji, který hnutí postupně prodělalo od počátku 20. století a s ohledem na nedůvěru panující vůči oficiálním strukturám, bývá často považováno přinejmenším za neslušné narušení přátelských vztahů, vystupuje-li jedna osoba zároveň v jedné situaci jako tramp a politicky činná osoba.

Trampské hnutí tedy nelze považovat za hnutí protestní ve smyslu moderních protestních hnutí [ $k$ tomu např. Marada 2003], jde spíše o způsob seberealizace, který může nabývat konfliktní povahy a který mohou někteří jeho účastníci za jistých okolností jako formu protestu vnímat, aniž by šlo o určující vlastnost trampingu jako celku. Aspekt revolty proti autoritám zde sleduje především neagresivně romantickou linii, která se projevuje hledáním lepšího, nezkaženého světa a idealizací mládí - v trampské kultuře je často možné nalézt právě takové projevy romantismu, jako „představu čistoty v protikladu ke zkaženosti, zdraví v protikladu k nemoci, upřímnosti v protikladu ke klamu, nepodmíněné lásky v protikladu ke kalkulovaným vztahům, nevinnosti v protikladu ke zkorumpovanosti, hloubky (prožitku, vztahu) v protikladu k povrchnosti, vitality a kreativity $\mathrm{v}$ protikladu $\mathrm{k}$ rutině, síly $\mathrm{v}$ protikladu $\mathrm{k}$ slabosti, přátelství v protikladu ke směně a nakonec i komunity v protikladu k odcizené společnosti“ [Marada 2003: 105]. Tramp-romantik si vytváří vlastní, částečně fikční svět, pro který jsou romantické hodnoty určující a, i když je mu zřejmá jejich omezená platnost a prosaditelnost v reálném světě, zejména ve světě institucionalizovaných sociálních interakcí, považuje je za natolik integrální součásti své osobnosti, aby jejich ohrožení vnímal jako útok proti sobě samému.

Za zmínku na závěr ještě stojí i jeden výrazný rys trampingu, který lze snad nejlépe, i když ne zcela přesně, nazvat hyperbolickým zveličováním skutečnosti. Tramping je do jisté míry hrou, ve které domácí poměry slouží jako náhražka exotických dobrodružství. Tento aspekt trampingu je dobře patrný např́íklad na názvech jednotlivých trampských osad a oblíbených míst, která dostávají exaltovaně romantická pojmenování. Trampové se stávají hrdiny Divokého Západu a výlety za město mohou být popisovány 
slovníkem dobrodružných románů. Hyperbola je zde spojena s patosem, který je, byt je někdy ironizován, obsažen i v sociálních interakcích mezi trampy. Mezi verbální projevy takového hyperbolicky patetického vyjadřování je možné zařadit například úvahy o definitivním úpadku trampingu, nerealistická tvrzení o jednotnosti hnutí a povaze trampů a zveličování významu různých trampských aktivit. Při výzkumu trampingu je nutné brát tento jeho rozměr $v$ potaz a uvědomit si, že některé popisy historických událostí a „bojů trampů s pađ’oury“ mohou být zveličeny nad obvyklou míru, například i formou „trampské latiny“. Zároveň je ale třeba si uvědomit, že pro některé respondenty, zejména vyššího věku, může takový obraz významu trampingu odpovídat jejich vnitřnímu přesvědčení a je nutno k takovým podáním událostí přistupovat s respektem. 


\section{Literatura}

Altman, Karel. [2003]. ...jak někteří trampují. In. Pospíšilová, Jana (ed.). Rajče na útěku. Kapitoly o kultuře a folkloru dnešních dětí a mládeže s ukázkami. Brno: Doplněk, s. 255-285.

anonym. [1929a]. Tisíce vás bude nyní volit. In. Tramp 15/1929, s. 4.

anonym. [1929b]. Kamarádi, uvažujte! In. Tramp 7/1929, s. 3.

anonym. [1930a]. Stal se malér. In. Tramp 6/1930, s. 3.

anonym. [1930b]. Veleváženému, velectěnému, veledobrému a slovutnému poslanci Jiřímu Stř́ibrnému. In. Tramp 8/1930, s. 2.

anonym. [1930c]. Kameny, kterými jdou do nás. In. Tramp 19/1930, s. 3.

anonym. [1931a]. Jihočeská slezina trampů v Českých Budějovicích. In. Tramp 5/1931, s. 11.

anonym. [1931b]. Brak nejhnusnější. In. Tramp 32/1931, s. 3.

anonym - Valigurová, Anežka. [1963]. Jak na tělovýchovu, sport, tramping, turistiku? Na otázky Mladého světa odpovídá tajemnice ÚV ČSM Anežka Valigurová. In. Mladý svět 7/1963, s. 11. Berka, M. [1991]. Posázavský Pacifik. Praha: Nakladatelství dopravy a spojů.

Břečka, Bruno. [1999]. Kronika čs. skautského hnutí. Brno: Brněnská rada Junáka.

Dědek, Vašek. [1930]. Tramping a „tramping“. In. Tramp 17/1930, s. 3.

Doležalová, Jarmila. [1979a]. Tramping a zákon. Samizdat - fond knihovny Libri Prohibiti, sig. TRAM 3761.

Doležalová, Jarmila. [1979b]. Tramping a zákon II - dodatky. Samizdat - fond knihovny Libri Prohibiti, sig. TRAM 3762.

Heřmanský, Martin - Novotná, Hedvika. [2011]. Hudební subkultury. In. Janeček, Petr (ed.), Folklor atomového věku. Kolektivně sdílené prvky expresivní kultury v soudobé české společnosti, s. 89-110.

Hurikán, Bob. [1992]. Dějiny trampingu. Praha: Novináŕ.

Jenč, Petr - Peša, Vladimír. [2006]. Projekt Obnova skalních dutin stavu přírodě blízkému v CHKO Český ráj. In. Jenč, Petr - Šoltysová, Lenka (eds.), Pískovcový fenomén Českého ráje. Turnov: ZO ČSOP Křižánky, s. 41-50.

Krško, Jan. [2008]. Meziválečný tramping na Rakovnicku. Praha - Rakovník: SoA Praha - SoA Rakovník.

Kučerová, Blanka. [1997]. Tramping po roce 1945. Diplomová práce. Praha: Fakulta tělesné výchovy a sportu Univerzity Karlovy.

Marada, Radim. [2003]. Kultura protestu a politizace každodennosti. Praha: Centrum pro studium demokracie a kultury.

Melíšek, Karel. [1929a]. Co nás zajímá. In. Tramp 7/1929, s. 10.

Melíšek, Karel. [1929b]. Občané pokojní a počestní. In. Tramp 11/1929, s. 3-4.

Melíšek, Karel. [1930a]. Slezina a co se kolem ní seběhlo. In. Tramp 18/1930, s. 3.

Melíšek, Karel. [1931a]. Do nového roku a ročníku. In. Tramp 1/1931, s. 2.

Melíšek, Karel. [1931b]. -a trampovat se bude! In. Tramp 4/1931, s. 3.

Moidl, Zdeněk - Moidlová, Olga. [2010]. Sbírka trampských domovenek a jiných atributů. Liberec: ROSA.

Petrová, Jana. [2009]. Zapomenutá generace osmdesátých let 20. století. Nezávislé aktivity na Plzeňsku. Plzeň: Jana Petrová.

Smoljak, Ladislav. [1961]. Trampové nejsou kovbojíčkové. In. Mladý svět 45/1961, s. 11-12.

Tunkl, Jiří - Weigel, Jaroslav. [1968]. Jetřichovice 6.-7. července 1963. Kolem Krvavého potlachu. In. Mladý svět 22/1968, s. 8-9.

Vinklát, Pavel D. [2004]. Kronika trampingu v Jizerských horách 1934-2004. Liberec: Knihy 555.

Waic, Marek - Kössl, Jiř́i. [1992]. Český tramping 1918-1945. Praha - Liberec: Práh - Ruch. 


\section{Webové stránky}

OTR - diskuze. Roverky. < < http://ontheroads.net/services/chatbox/chatbox.php?WhatView = $=$ read $\& I d=4229>$ [30. 8. 2010]

OTR - diskuze. Tramping vs ochrana př́rody, ubývání „divočiny“, .. < http://ontheroads.net/ services $/$ chatbox/chatbox.php? WhatView $=$ read\&Id $=579>$ [30. 8. 2010]

Roverky - <http://www.roverky.cz/ > [30. 8. 2010]

\section{Respondent}

M. Korba (nar. cca 1960), Popovice u Berouna, opakované rozhovory v letech 2003-2010.

Jan Pohunek (1981) vystudoval archeologii a etnologii, v současnosti je postgraduálním studentem Ústavu etnologie Filozofické fakulty Univerzity Karlovy a pracuje jako etnolog $v$ Regionálním muzeu v Jílovém u Prahy. Dlouhodobě se zabývá moderním folklorem a různými projevy vztahů lidské kultury a krajiny. 